\section{THE COMPREHENSION OF PLACE AWARENESS IN A HISTORICAL CONTEXT: METAPHORS IN ARCHITECTURAL DESIGN EDUCATION}

\author{
Esra ÖZKAN YAZGAN*, Aysu AKALIN*
}

Received: 10.09.2017; Final Text: 01.02.2019

Keywords: Place awareness; historical context; Aizanoi; architectural design education; cognitive operations.

\footnotetext{
* Gazi University Faculty of Architecture, Department of Architecture, Ankara, TURKEY
}

\section{INTRODUCTION}

Metaphors enable structural alignments to be established between a design problem and other remote domains and help to project a system of deep relations that assist in dealing with the problem at hand (Gentner et al., 2001). They influence the way people think, perceive, and categorize experiences and concepts in their minds (Lakoff, 1993). Weisberg describes the instances where metaphor is used as "...transfer situations in which information from a previous situation is transferred to the new situation that is analogous to the old" (Weisberg 1995, 62).

In fact, metaphors are considered to be powerful problem-solving tools for dealing with design tasks. They allow us to understand a relatively abstract or inherently unstructured subject matter in terms of a more concrete or at least more highly structured subject matter (Lakoff 1993, 245). As mentioned by Barie Fez-Barringten $(2012,4)$ metaphors are transferring, bridging and carrying-over where transfer can bridge anything to anything and has consequences.

Throughout architectural design education, students are expected to understand the current context of the places where they work and to generate architectural designs that can be integrated with this context. In this sense, design problems can be defined with the help of metaphors, and the context of place can be transformed into designs. As Coyne notes, teaching design involves organizing situations that furnish students with experiences in which helpful metaphors emerge (Coyne et al., 1994). Metaphors defined as "..a description of an object or event, real or imagined, using concepts that cannot be applied to the object or event in a conventional way" (Indurkhya, 1992, 18) provide beginning design students with a framework in which to develop their own ideas and personal skills in design problem-solving (Casakin, 2006). They can improve students' performance by encouraging reflection on design problems (Schön, 1984). 
In design, metaphors are viewed as heuristics that help organize design thinking and handle ill-defined design problems (Casakin, 2007). The power of metaphor has been appreciated by respected architectural educators who consider it "the bedrock of imagination" (Antoniades, $1992,30)$. As mentioned by Barie Fez-Barringten $(2012,1)$ imagination is the backbone of metaphors and metaphor is the key to the design. Using metaphors, designers can enlarge the range of potential design solutions by comprehending unfamiliar problems (Casakin, 2004). According to Casakin (2006), as an educational approach, metaphors contribute to an enhancement of design thinking capabilities, yield a better understanding of the design process, and improve critical design abilities. Casakin $(2004,2006,2007,2012)$ has carried out a series of empirical studies about metaphors and architectural design problem solving. As he mentioned;

“...metaphors were found to be slightly more helpful and less difficult to use in the early stages of the design process, known as conceptual design. They were less helpful and more complex to use in the final stage of the design process" (Casakin, 2006, 265).

According to Fez-Barringten $(2012,19)$ what is designed and what is read as metaphorical language is not the metaphor but a surface manifestation of the concept metaphor. It is a concept which we can only know as well as we are able to discern metaphorical language. The construction and the metaphor beneath are mapped by the building being the manifestation of the hidden conceptual metaphor. One may perceive a design problem in a variety of ways. The specific perception, together with the original program, will identify just what is at issue and, hence where the stasis lies. Fez-Barringten describes in reasoning metaphor stasis (the heart of the metaphor) referring to the focal point of a metaphor, the point at which contending factors meet where it is the commonplace in combination with a complex weave of dominant, subdominant and tertiary metaphors. In a work of architecture, once the metaphor is created the stasis is established when people negotiate the work and find the place where they meet the essence of the metaphor, a place of equipoise (Fez-Barringten 2012, 54, 55). The term means "point of rest" (equipoise) between opposing forces. The stasis which enables us to identify precisely what is the difference and invites users to perceive what is established as the meeting place or topoi between the creation and the perception of the metaphor. After assimilating the program in the process of making a habitable conceptual metaphor, the very first step in the design process is to develop a "parte" as (presumptive) resolutions of a program. It is a "top-down" approach later followed by designs which meet the "parte" (concept/gestalt). Alternatively, the "parte" may follow the design process and be presented to defend the design. Uniquely, what determines the stasis is not the original design but the response to it. Once achieved the stasis, parte manifests and can be articulated (Fez-Barringten, 2012, 29, 57, 61).

The metaphors used in architectural design studios are mostly related to concepts presented by the tutors and rarely concerned with the relationship between concepts and context, which is place awareness. This awareness has also been defined as familiarity with "the spirit (essence) of a place" by Norberg-Schulz (1996), sometimes also called "genius loci" or used for "sensing" place to denote an effort to sensitively come to know the nature of a place. Norberg-Schulz (1980) claims that the genius loci of a particular place is important for our sense of identity, which may be bound up with a particular place. The location itself marks the position of the place but place itself consists of the totality of the natural and man-made things, assembled 
in a unique way. While all places have a character, this in itself is not adequate to induce genius loci. It is the uniqueness which makes it special and with which we can readily associate. Norberg-Schulz argues that when a focus on the identity or genius of a place is absent or forgotten, the result is "loss of place" (1980, 189-190).

The spirit of a place is unseen or hidden, awaiting to be discovered and architecture, by its own language, plays a significant role in revealing and reintroducing the spirit of a place. It is a "bridge", described by Martin Heidegger $(1971,143-59)$ that links man and nature together by giving the opportunity for man to participate and interact with nature. Referring to the example of the bridge in Heidegger, Norberg-Schulz argues that; "The landscape as such gets its value 'through' the bridge. Before, the meaning of the landscape was 'hidden' and the building of the bridge brings it out into the open" (Norberg-Schulz, 1980, 18).

Thus, the task of architecture is to transform a site into a place, "to uncover the meanings potentially present in the given environment" (NorbergSchulz, 1980, 18).

This paper presents the complexity of the use of metaphors by secondyear architecture students in a particular design problem, the generation of goals and constraints for the students and the application of contextual relationships to a design problem using metaphorical reasoning.

\section{THE COGNITIVE OPERATIONS OF METAPHORICAL REASONING}

Researchers have identified different cognitive operations that explain metaphorical reasoning. For instance, van de Kamp et al. (2016) lists three specific generative cognitive activities: association, combination and abstraction. They built a model of twelve divergent thinking activities, along two dimensions: remoteness (metaphorical distance from the stimulus) and abstractness. Their model is a matrix of creative and generative activities running from zero remoteness/concreteness to remoteness/abstractness. To describe the creativity of adolescents, Lassig (2013) uses four cognitive operations: adaptation, transfer, synthesis and genesis.

Like Lassig (2013), Welling (2007) lists four different cognitive operations: application, analogy, combination and abstraction. "Application" is the adaptive use of existing knowledge in its habitual context. This operation is virtually identical to the term "conceptual replication" defined by Sternberg as replication "...under circumstances somewhat different from those that originally gave rise to it" (Sternberg 1999, 92).

Analogy can be defined as a connotative meaning and considered as an important design input (Akça et al., 2015). It implies the transposition of a conceptual structure from one habitual context to another innovative context (Welling, 2007). Unlike application, detecting and implementing an analogy is generally accepted as a creative act. As mentioned by Barie Fez-Barringten $(2012,70)$ analogies can be either literal or figurative, that is, they can be direct comparisons between things or comparisons of the relationships between things. "Combination" is the merging of two or more concepts into one new idea, either spatially or temporally, in which the combination results from the sequential application of existing ideas (Simonton, 1999). Mumford et al. (1991) have stated that creative thought comes from the new combinations of old ideas. They have added that 
combination can not only be obtained by the blending of previously distinct concepts, but also by the re-arrangement of elements within an existing concept. Piaget (1968) first proposed "abstraction" as a solution for new knowledge in his work on genetic epistemology. He distinguished between empirical abstraction - focusing on objects - and reflective abstraction - focusing on mental concepts and actions. The underlying operation of "setting up a correspondence" (Piaget, 1968, 18) is the same for both types of abstraction, suggesting that new abstract knowledge is built on top of other existing knowledge, so that new knowledge always depends on existing knowledge. This refers both to the mental process as well as to the product of this process. The mental process of abstraction may be defined as the discovery of any structure, regularity, pattern, or organization that is present in a number of different perceptions that can be either physical or mental in nature. Root-Bernstein $(1991,87)$ has defined abstraction as a process of simplification and the "elimination of unnecessary detail to reveal underlying order, pattern or structure". In discussing some works of abstract art, Root-Bernstein and Root-Bernstein (1999) gave the impression that the process of simplification and stripping of detail led to the discovery of abstraction. That is, once the relationships between entities are discovered, they can be more clearly demonstrated in a simplified representation leaving out the unnecessary detail (Welling, 2007). Explicit reference to the role of abstraction can be found in Ward et al. (2004), who have demonstrated that encouraging abstract thought results in increased originality.

Cognitive operations and skills include: intelligence, attention, memory, perception, information processing, associative processes, problem finding, problem solving, insight, intuition, unconscious processes, mindfulness and more importantly, metaphorical reasoning (Runco, 2007). Metaphors affect the way we perceive the world, categorize experiences and organize our thoughts. They have a fundamental role, as they not only enhance innovative thinking, but also guide reasoning and thinking. Metaphorical reasoning is an iterative process through which designers gradually increase their knowledge of a design situation by restructuring design problems in a non-routine way (Antoniades, 1992). According to Barie Fez-Barringten "thinking rhetorically" means reasoning with audience predispositions in mind, a definite prerequisite in architectural design and the function of the metaphor to make the strange familiar $(2012,1,10)$. It is the job of the design professional to ascertain these differences. As Fez-Barringten mentions $(2012,11)$ we are virtually all about metaphors between each other and our surroundings and design respects different ways of thinking and reasoning and metaphor is the main mechanism through which we comprehend abstract concepts and perform abstract reasoning (Lakoff 1993, 244). Casakin (2007) believes that metaphorical reasoning facilitates the generation of innovative solutions, mainly in the earlier stages of the design process. It is assumed to be associated with abstract motifs such as imagery and feeling in stimulating design thinking.

\section{ARCHITECTURAL DESIGN STUDIO EXPERIENCE IN AIZONAI}

The architectural design studio work presented in this paper deals with cognitive operations in the design studio and the application of concepts to a design problem. The metaphorical reasoning in the problem-solving exercises of architectural design education has been considered as cognitive operations in Welling's (2007) study of the creative process of individuals 
Table 1. The cognitive operations (adapted from Welling, 2007) involved in place awareness.

\begin{tabular}{|c|c|l|l|}
\hline low place awareness & \multicolumn{1}{|c|}{ high place awareness } \\
\hline \multicolumn{1}{|c|}{ Application } & Analogy & Combination & \multicolumn{1}{c|}{ Abstraction } \\
\hline $\begin{array}{l}\text { adaptive use of } \\
\text { existing knowledge }\end{array}$ & $\begin{array}{l}\text { transposition of a } \\
\text { conceptual structure }\end{array}$ & $\begin{array}{l}\text { merging of two or } \\
\text { more concepts into } \\
\text { one new idea }\end{array}$ & $\begin{array}{l}\text { elimination of } \\
\text { unnecessary } \\
\text { detail to reveal } \\
\text { underlying order }\end{array}$ \\
\hline
\end{tabular}

and exploration of the mental representations and thinking skills involved in creative thinking. This study seeks to comprehend the relationships between cognitive operations and place awareness. Cognitive operations ensure the communication of the context with the architectural product. In this sense, they create an architectural grammar and fill it with form, content and context (Koca and Uluengin, 2014). By analyzing a studio process, the paper discusses how second-year architectural students might sense the space in which a "nexus of ideas" (Brook, 2001) captured from the site to implement into a design process. Application is not preferred by architecture students or their tutors. Low place awareness is based on tangible/concrete and objective features and analogy, while high place awareness involves abstraction and is based on intangible and conceptual/ subjective features (Table 1). The details of this study are presented below.

\section{Method}

Firstly, it is believed that an awareness of "place" is an important objective in architectural design education. To achieve this, architectural students should be encouraged to engage in visits to historical sites to help them feel Norberg-Schulz's "spirit of the place". Uraz and Balamir (2006) have described how working in a historical context gives a sense of responsibility towards delicate environments that possess cultural heritage. The historical site visited for the second year spring term 20162017 academic year studio project was Aizanoi Çavdarhisar in Northwest Anatolia.

\section{The Site: Aizanoi Çavdarhisar}

Çavdarhisar is a settlement built on the ancient city of Aizanoi, $50 \mathrm{~km}$ from the city of Kütahya, which was the centre of Aizanitis, in ancient Phrygia, settled since 3,000 BCE. In 133 BCE, Aizanoi had come under Roman rule. In that period, the town became rich from its production of grains, wine and wool. By the end of the $1^{\text {st }}$ century $\mathrm{CE}$, the town began to turn into a city, which eventually became the centre of episcopacy in the second and third centuries, but lost its influence in the $7^{\text {th }}$ century. During the time of the Seljuk Principality in the $13^{\text {th }}$ century, Çavdar Tatars used this area as a military base, giving the community its present name Çavdarhisar, which translates into English as "Çavdar Fortress" (Rheidt ,1998, 3-19).

Most of the archaeological remains from Aizanoi are located on both sides of the Kocaçay (Penkalas) River. Displaying a division between the two banks of the river, the shape of the town was dictated by the topography that allowed a linear growth of the settlement $1 \mathrm{~km}$ in length. Two out of the four Roman era stone bridges on the river are still in use today. The inscriptions on the pedestal of these bridges' railing date them to September 157 BCE. The other ancient remains to be found at Aizanoi Çavdarhisar include a well-preserved Temple of Zeus, the Complex of Stadium-Theatre, Macellum (one of the first exchange markets in the world), two Roman baths (one of them decorated with mosaics), Portico 


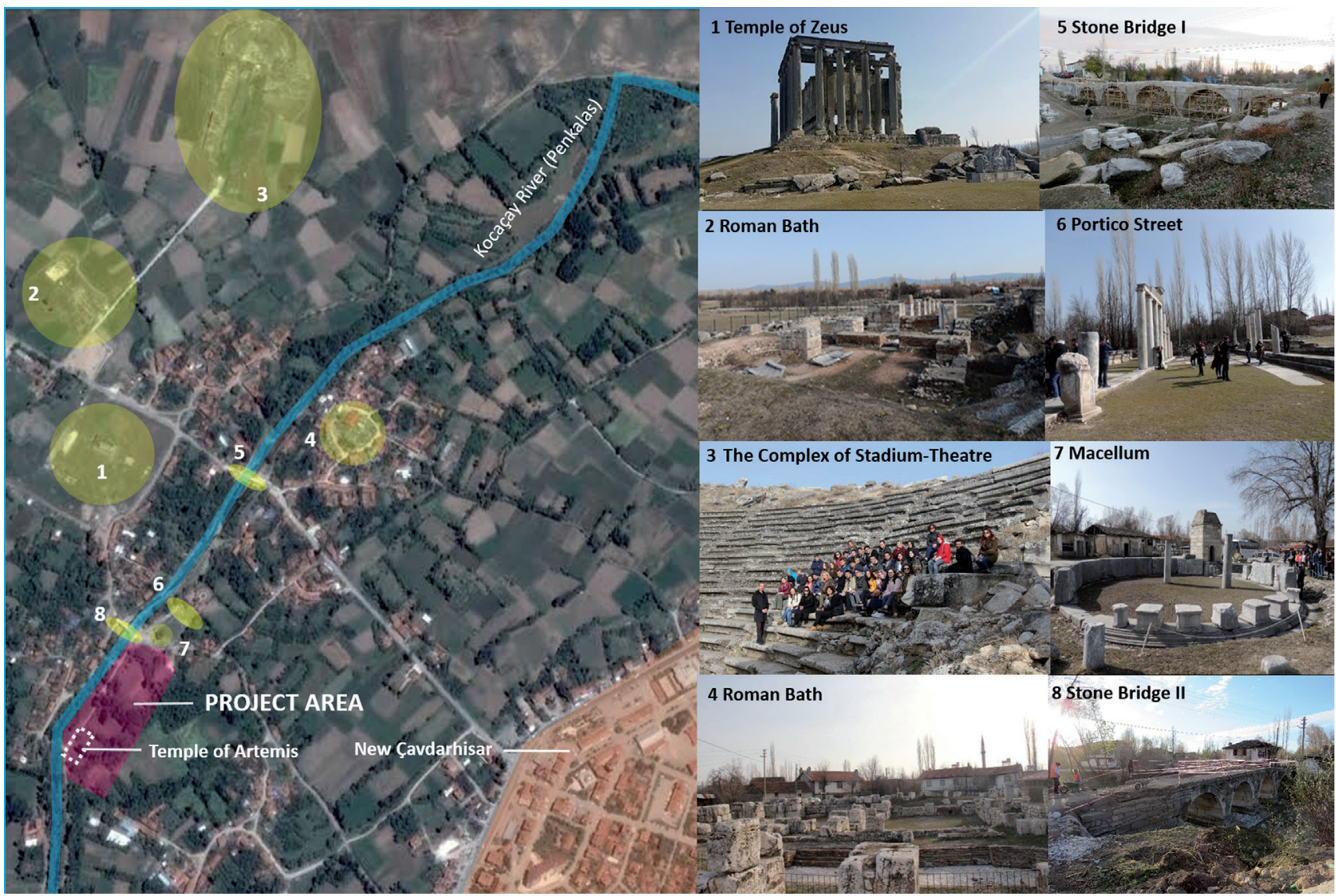

Figure 1. Map (Google earth, 2017) and photographs of Aizonai, showing the historical sites and project area.
1. Conservation Plan Report of Aizanoi Ancient City Archeological Site and the Urban Archeological Site $(2011,68)$

2. See Unesco Tentative List (UNESCO World Heritage Centre, 1972)
Street, Agora and Gymnasium (Rheidt, 1998, 3). The existence of a Temple of Artemis is also known. Some of the columns of this temple have been used to restructure the Portico Street(1). The modern settlement of Çavdarhisar was seriously damaged in the 1970 earthquake and was subsequently moved $1 \mathrm{~km}$ southeast of the ancient city (Figure 1).

Most of the visible remains of the city are from the period of the Roman Empire. The Temple of Zeus - the biggest and the most spectacular element of the village - is located at the highest altitude, dominating the whole city. The Macellum and the Portico Street define a main square. There used to be a mosque built on the ruins of the Macellum, but this was demolished by the 1970 earthquake, and the Macellum remnants were discovered (Özer and Korkmaz, 2014). Today, only a partially demolished minaret remains. A newer, smaller and not properly built mosque is located very near to the main square. One of the Roman bridges connects the village square to other side, directly to the Temple of Zeus. The agora and gymnasium are located $1 \mathrm{~km}$ north of the village square and cannot be seen very easily. Scientific excavations at Aizanoi began in 1926 and continue to be carried out today (Rheidt, 1998,3).

The present texture of Çavdarhisar consists of a mixture of these ancient remains and a combination of traditional residences built at the beginning of the $20^{\text {th }}$ century. Aizanoi Antique City was listed on the UNESCO Tentative List of World Heritage in 2012 (2). Today, Çavdarhisar looks almost like a deserted area with only about fifty families living in partly ruined houses. In the past 30 years, most of the local residents migrated to the new Çavdarhisar town built after the 1970 earthquake. As a result, 
this multi-layered settlement, which includes archaeological remains of a distant past and traditional residences of the immediate past, presents a unique environment for a discussion on architectural awareness to discover the spirit of the place.

\section{The Draft Program}

The design problem for the students was to propose a Visitor Centre - a meeting place for the first time visitors - that would also include cultural and recreational areas for local residents. The main question for the students was to designate where to locate that visitor center in Aizanoi Çavdarhisar and design a Visitor Centre where tourists would get information and watch presentations related to the site. A draft spatial program issued to the students - for guidance only - included a main foyer with presentation-communication kiosks, venues for audio-visual presentations, and a brochure-map-guidebook section, an exhibition hall, seminar hall(s), commercial units and a café. The indoor area to be designed was roughly $1500 \mathrm{~m}^{2}$. Regarding the needs of the local Aizanoi Çavdarhisar residents, alternative programs for indoor and outdoor uses were expected from the students to help organize the meeting place and the nearby area. These alternatives were proposed by the studio instructors again, for guidance only; as socio-cultural activity centre, traveler accommodation, a public market, and recreation areas. These were not expected to be planned in detail, just only as site proposals. The students were free to develop this Visitor Centre and the facilities to serve the cultural and recreational needs of the local residents by adding or excluding elements with valid reasons. Similarly, possible sites were offered to the students and left free to them to decide. Regarding all the historical remains at the site, the students were asked to propose a scenario (trip route) for first time visitors.

\section{Before the Site Visit}

At the beginning of the term, discussions developed in the studio around place awareness and the above-outlined program. These discussions were basically about the site and the context that would be studied for the entire term. At this time, the students were advised to observe the environment carefully during the upcoming site visit and feel the details of the place, but they were never explicitly told exactly which details they should look at. Some examples highlighting or ignoring the importance of context in historical textures were presented in the studio, and each example was discussed in detail and students were asked to find more design examples applied in historic textures. The class also had a web page, which gave both tutors and students a chance to share examples related with this topic. In fact, all members of the studio (tutors and students) very enthusiastically used this web page to interactively share knowledge throughout the entire term, not just this initial pre-site visit phase.

\section{The Site Visit and the Proposed Sites}

Later, a site visit with the tutors was undertaken for two days. This provided the students with an integrated understanding of the site details of Aizanoi Çavdarhisar. To engender an architectural place awareness, the students were encouraged to read the site based on their first-hand experience of their bodies moving through the project environment, to develop a sensorial relationship with it, rather than relate to it solely through plans or photographs. While at the site, besides the historical values, the students were asked to concentrate on materials, structural 
3. According to Norberg-Schulz (1996), "character" denotes the general "atmosphere" which is the most comprehensive property of any place.

4. In the spring term, there were 35 second year students in the studio who had single family housing project experience from the previous semester. They were divided into two groups, each overseen by two tutors. During the 14 weeks of the term, the studio conducted three mid-juries and one final jury. The studio took place 2 days a week, each session lasting 4-5 hours or more. To let each instructor know the process that a student made until the jury, different instructors took the turn of one group and each instructor taking one group for discussion occupied the studio time. While each student got critiqued by the instructor the others in the group were encouraged to join and express their own ideas. Regarding the methodology of the studio, there were four phases in each semester. The first one was called Preparation, which included experience of the site with a detailed survey and modeling of the site on which possible conceptual studies could be carried out. In addition, though the instructors gave a draft program, the students gathered data about the facilities in detail. At this early phase, studio instructors informed the students with well-organized presentations. Before a Final Phase, the studio education developed along two main phases. In Progress 1 Phase, students were encouraged to work with conceptual sketches and conceptual models simultaneously, representing the rough image of the program to stimulate their creativity and artistic skills. In Progress 2 Phase, drafts and concrete models concerning the full program were made.

5. The final design stage of students has been evaluated according to their process during the 14 weeks of education. Since the basic concept of the studio is to help student to sense the genius loci, the instructors were accustomed to mimetic projects. For this reason, it was easy for them to distinguish design approaches that were graphical and those that sensed the place with metaphors. For the final jury the external examiners were invited to ask questions and to evaluate but not to grade. The studio instructors evaluated and graded each project independently and for the final grade, the averages of all grades were calculated. details, textures, colors, solid-void relations, scale and the spatial layout constituted by cul de sacs, narrow streets and squares.

Since they were second year students with limited experience, they were not entirely left free to choose a site. In Aizanoi Çavdarhisar two sites were proposed to the students: the first was between the Portico Street and the ruined Temple of Artemis, the second one was between the village square and the antique bridge to the north including the Macellum, the Portico Street, and historical houses. Mostly, the students preferred the first site.

\section{After Returning from the Site}

After conducting two days of intense site analysis, once back from their site visit the students were asked to consider their understanding of the sense of the place where they had been. In order to keep the students focused, they were asked to translate into words their intuitions from the site. At first, the tutors and the students were engaged in the debate about the character(s) of the site (3). It was believed that talking about feelings and intuitions after the site visit would make the students aware of what they missed and what to look for the next time. At the end of term, for their final submission, the students were asked to prepare another report explaining what they had been through in the last 14 weeks of class (4). The aim of these two written exercises was to understand the difference between the intuitions through sensing at the beginning of the design process and the feelings of the place at the end of the process. Both reports were important to understand how each student read the site, was influenced and picked up which details, their clues or nexus of ideas. After each student decided upon a particular design situation, conceptual relationships were developed until a suitable design solution was reached. Some of the studio projects are evaluated in detail below.

\section{ANALYSIS OF THE STUDIO EXAMPLES}

Empirically, it is aimed to explore how beginning architectural design students perceive a design problem during the early stages of the design process. It is believed that those students who fully research the problems related with the historical context and the main question of the spirit of the place are more likely to be successful.

The reports done both at the beginning and at the end of the research indicate that the students generally mention the tangible aspects with a subjective language such as incredible height of the Temple of Zeus and the Portico Street or the unbelievable width of the Roman bath. The students' final work involved more detailed explanations as a direct result of their experience on the site. These were the intangible aspects of the site, which are subject to individual interpretation. For instance, feeling of falling in a vast empty space while entering Temple of Zeus from its vaulted section, affection of chaos while walking along the houses with intersecting roofs, feeling the screams of the historical values under the earth in layers awaiting to be excavated.

Analysis of the projects identified two different views of the beginning architecture students: some students underlined the importance of the historical context without metaphorical reasoning (Table 2), and others emphasized the context by considering analogies/metaphors and stressing the spirit of the place (Table 3, 4, 5)(5).Those student projects without metaphorical interpretation were less sensitive to the spirit of the place and the site's characteristics (Figure 2, 3, 4). They behaved graphically stressing 


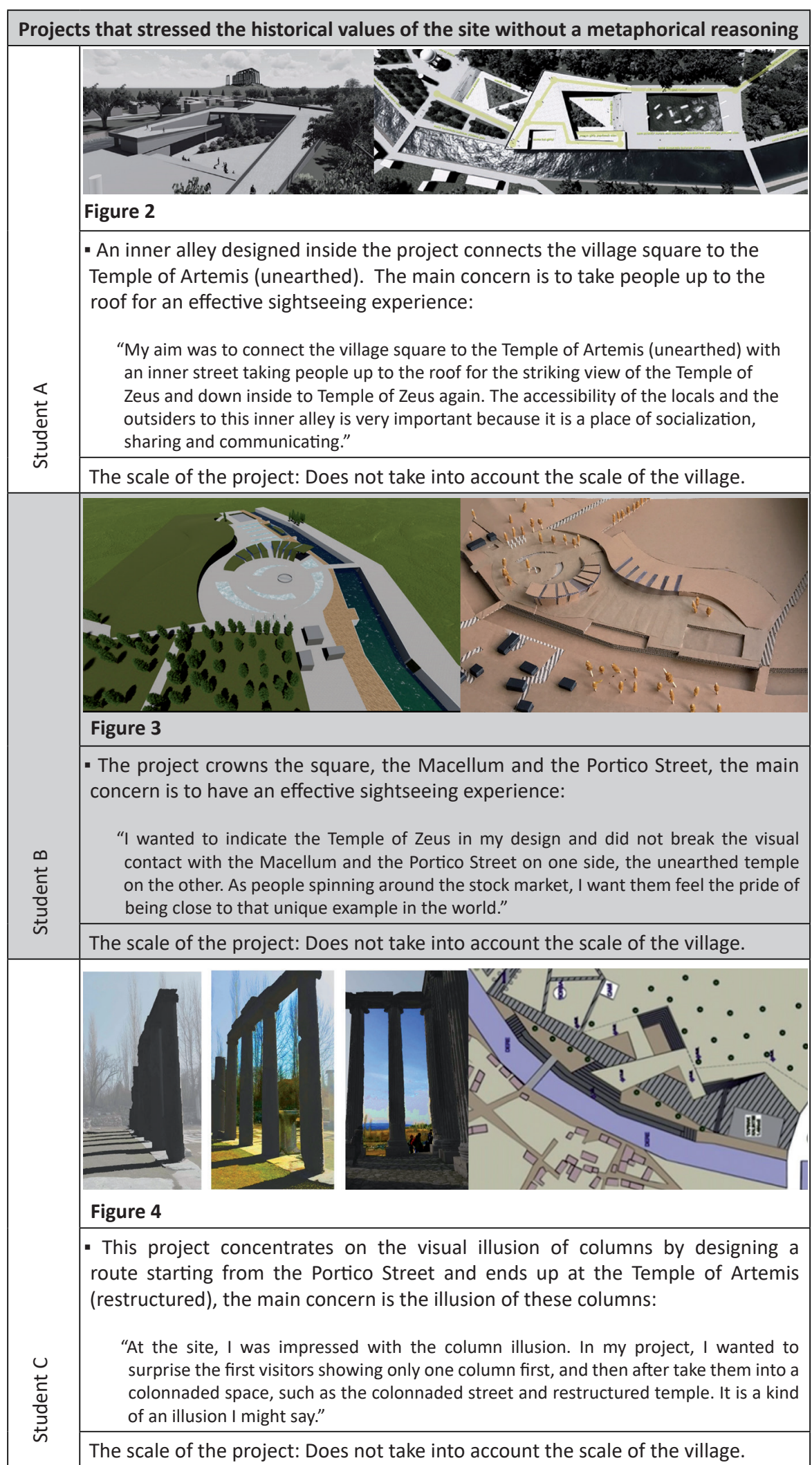

the importance of the historical context without a metaphorical reasoning. These students were very good at graphical representation of the main question and the scale of the structures they designed (regarding the 
6. In fact, regarding cognitive operations, the application of existing knowledge is not the method suggested and applied in the architectural design studio. According to Rapoport $(2006,182)$, students must be discouraged from the copying of certain formal qualities (shapes, massing, details and alike), often based on a "romanticized version of the vernacular". Instead they must have the courage to analyze principles of vernacular environments and apply these principles to design.

7. Some of the students in the studio proposed reconstructing physically the Temple of Artemis, others reconstructing it virtually while others preferred to keep only the ruins for their designs. existing context) was not their main concern as if they had forgotten where the project was located. In most of the examples, graphic enthusiasm with exaggeration in scale outpaced place awareness (neither tangible/objective, nor intangible/subjective features were applied) For those projects, the functional requirements and accessibility, both outside and inside, were more important than the spirit of historical values at the site (Table 2).

The students who sensed the place with metaphors and emphasized the spirit of the place were aware of the architectural uniqueness of the historical remains and the importance of natural values of the site such as topography, forest, river, and alike in their projects. Regarding the projects based on metaphorical reasoning, three different cognitive operations with respect to the place awareness were detected: analogy, combination and abstraction (6). Place awareness was quite low with analogy based on tangible/concrete and objective features applied, significantly increased with abstraction based on intangible and conceptual/subjective features, and was at the highest level with combination cognitive operations based on both tangible/objective and intangible /subjective features. Some of the students emphasized the Temple of Zeus and/or the Macellum and the Portico Street and/or the Temple of Artemis (7). They were aware of the two Roman era stone bridges on the river, the two Roman baths and most importantly, the traditional residences of the villagers. The details of these projects are presented below together with some quotes by the students (Table 3).

Analogical examples in the paper imply the transposition of a conceptual structure from the historical context to the designed context. Accordingly, some of the students preferred analogy by transposing objects existing on the site -such as one of the Roman stone bridges (Figure 5) or the ruined columns scattered all around the Temple of Zeus (Figure 6) -while others decided to make an analogy of the whole urban texture to map onto the new domain (Figure 7). The attitudes of the students were not a simple graphic imitation of the existing, but a purely semi-abstract representation with today's materials and technology. The modest scale of the urban texture was respected by most of these projects, except the first bridge analogy example.

The combination operation is the merging of two or more concepts into one new idea. Different from the analogy operation, it requires the creation of a new conceptual structure. Regarding the students' examples of combination, the existing structure was reinterpreted with a new conceptual structure. As Mumford et al. (1991) state, combination can occur by the rearrangement of elements within an existing concept, but of course with a new conceptual interpretation. Project of student G is actually the outcome of a perfect combination of both analogy and abstraction (Figure 8). The huge and glorious effect of the Temple of Zeus and the vaulted section under the temple were the details that impressed the student. A huge hill was created with restricted visual contact with the outside, and the vaulted section was interpreted and the mystic effect while entering the hole was abstracted. Considering the modest scale of the village, the project was designed by intelligently hiding the whole massy effect of the hill through camouflaging. Similarly, Student $\mathrm{H}$ is the combination of analogy and the abstraction (Figure 9). The intersecting effect of the house roofs on the whole site was interpreted with a new design concept and the chaos effect in the village abstracted through undetectable intertwined structures in a row. It was a complicated design solution for a second year student of 


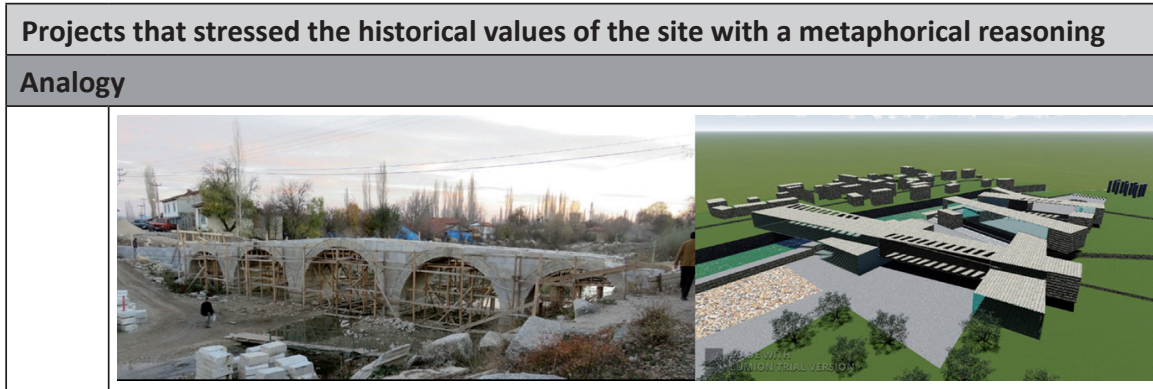

Figure 5

- By emphasizing the importance of the antique bridges, the main concern was to design an "activity bridge":

"The two historical bridges left today keep the dialog of the two sides of the village. I wanted to offer a cultural bridge where visitors come, meet and socialize. It is to strengthen the social ties of the locals and to led them socialize with outsiders as well."

The scale of the project: Does not take into account the scale of the village.

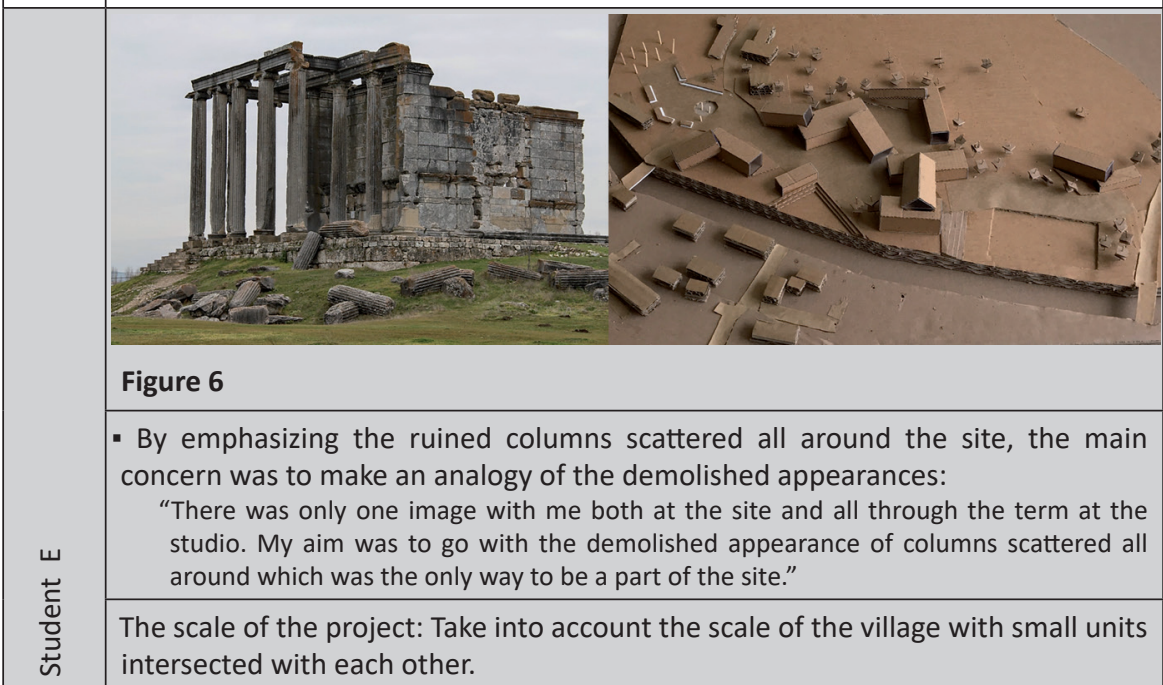

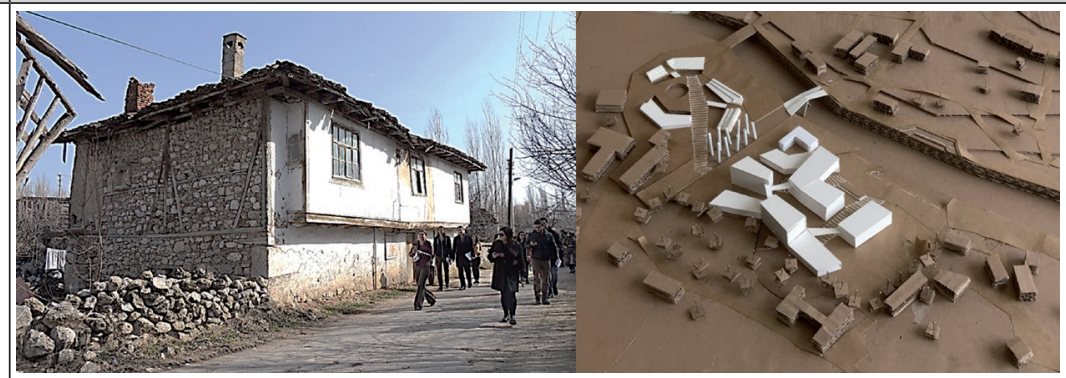

Figure 7

- By emphasizing the importance of the urban texture, the main concern was to make an analogy of the fragmented urban texture:

"As a first time visitor to Aizanoi Çavdarhisar, I was impressed to see different centuries side by side standing with no harm to each other. Despite the demolished looking of the village, the fragmented texture with cubic houses at the site was still recognizable. I thought identical cubicles of the $21^{\text {st }}$ century could enhance the value of the site while being a part of the site with no harm. This was all about my understanding of place

$\begin{array}{lll}\square & \text { being a part } \\ \sim & \text { awareness." }\end{array}$

The scale of the project: Take into account the scale of the village with small units intersected with each other. 


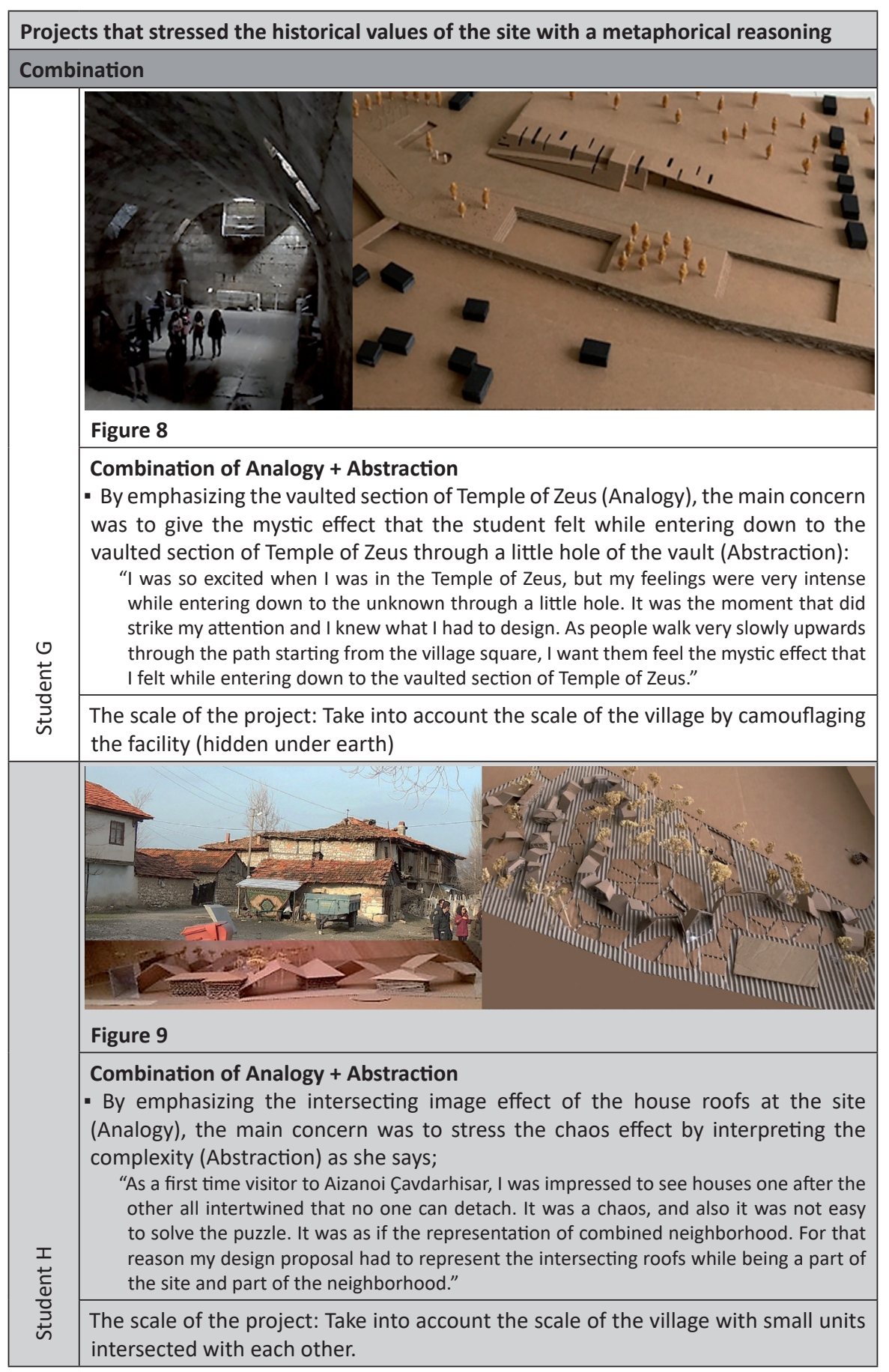

architecture to solve, but each managed with the help of conceptual models at first and later with physical models of different scales. As Martindale (1989) states novel actions and approaches with creative thought can be attained by new combinations of old ideas. As analogy-abstraction combinations, these two examples might be considered as successful proposals perfectly reflecting the spirit of the place (Table 4).

Abstraction operation examples in this paper are in the category of reflective abstraction, which focus on mental concepts and actions. Student $\mathrm{J}$ (Figure 10) concentrates on knitting different layers and Student K (Figure 


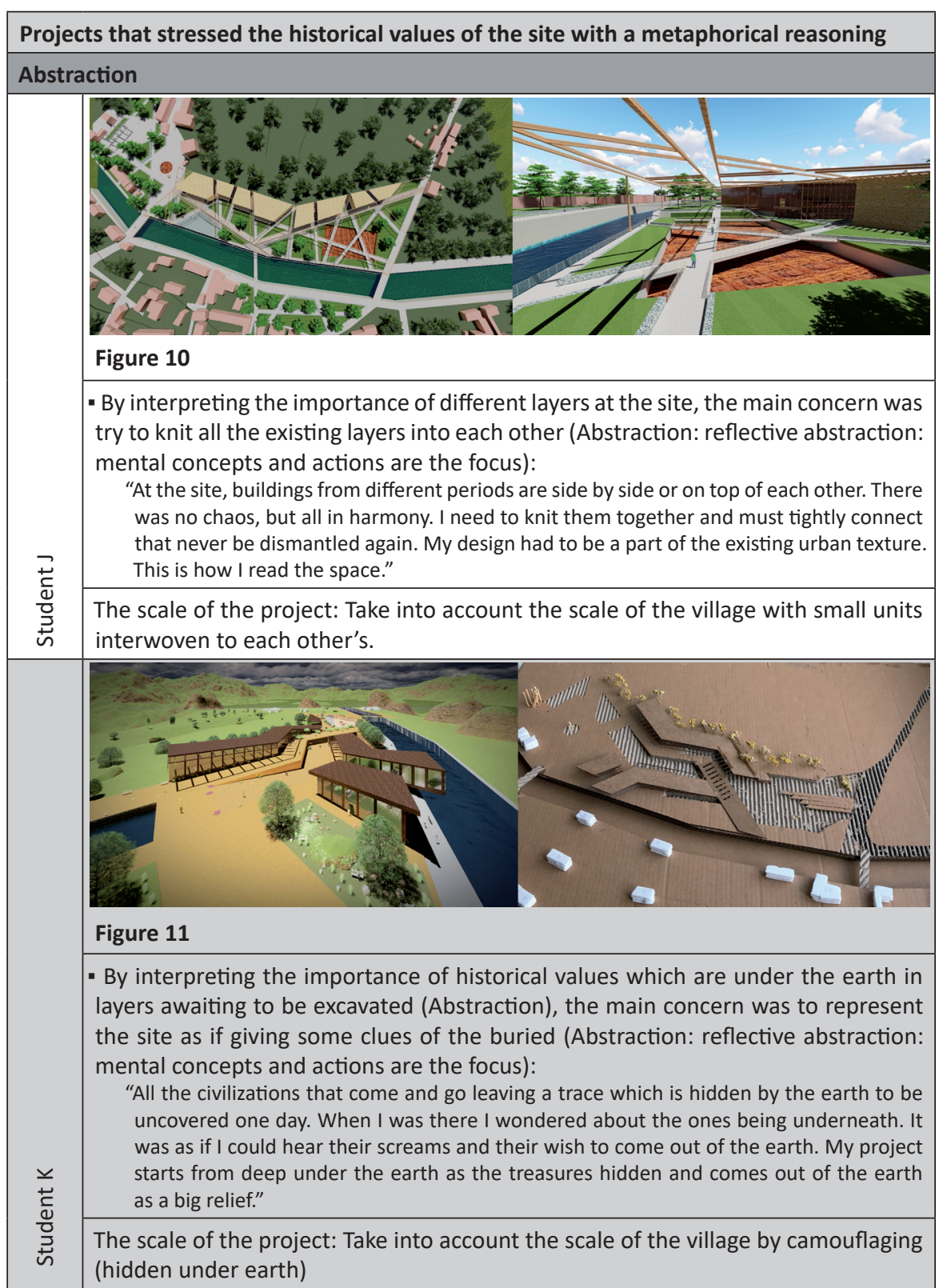

11) focuses on the values hidden in the earth. By eliminating unnecessary details, these approaches are a kind of setting up a correspondence as Piaget (1968) defines, that is the simplistic correlation structured between the abstract and the tangible. The new abstract one and the existing knowledge are all the time side by side or on top of each other inseparably. From the projects represented in the abstraction operation, it can be said that an abstract way of formulating the place can increase originality as the spirit of place is perfectly abstracted in connection with place awareness. This result has parallels with the study of Ward et al. (2004), who demonstrated that encouraging abstract ways of thinking usually results in increased originality (Table 5). 


\section{CONCLUSION}

An architectural design must tie first to the appropriate meanings of place, which thus provides continuity of the spirit of the place. An attempt to stress "continuity with" rather than "break from" the past (Carmona, et al., 2003 , 236) should be one of the ways of materializing the spirit of the place. The materializing of genius loci enhances the past by continuity with the aim of producing a setting densely packed with references to the stream of time rather than a stagnant setting that has never been changed. When designing in a historical context, the most problematic issue is how to materialize feelings by preserving the characteristics of place. The treasures of place and its surroundings, which envelop the place and our spatial existence in a totality, materialize the work of architecture. The main question is how to materialize the treasures stored in place and as Kim $(2013,156)$ notes this aim is the reason for dwelling and living.

As mentioned earlier in the paper, Fez-Barringten mentions stasis referring to the focal point of a metaphor, it is the point at which contending factors meet; metaphorically it is the commonplace, fertile, thriving and prolific (Fez-Barringten 2012, 54). In fact, the metaphor is the conceptual focal point in design to acquire the place awareness "the spirit of a place" as defined by Norberg-Schulz (1996), and the "equipoise of stasis" is the key factor for creating a strong bond between the concept and the context. As described in this paper, the mimetic approach through cognitive operations provided an opportunity for students to acquire an awareness of the place and to materialize the treasures stored in place. Low place awareness is based on analogy, which is the transposition of the conceptual structures based on tangible/concrete and objective features, and high place awareness is based on abstraction, which is related to mental concepts and actions based on intangible and conceptual/subjective features. Antoniades (1992, 30) believes that relying solely on either tangible metaphors or intangible metaphors is not ideal and introduces a third category of architectural metaphor: the combined metaphor, which he defines as: "those in which the conceptual and the visual overlap as ingredients of the point of departure" or literally, the combination of both tangible and intangible metaphors. The results of this research show that, not only the abstract way of thinking described by Ward et al. (2004), but also projects in the category of combined cognitive operations seem to increase originality.

Cognitive operations appear to be quite appropriate tools for solving design problems since they unite rationality and imagination. As Casakin notes (2007), they help designers to understand unfamiliar problems by juxtaposing them with known situations. They serve in the comprehension, concretization and description of the context, and they are also important intermediaries in the creation of an architectural product. This is because they are the thoughts that ensure the communication of the context with the architectural product. In this sense, they create an architectural grammar in the transformation of concepts into products (Koca and Uluengin, 2014). Therefore, the second-year students' mimetic attitudes were engaged in a debate about the character(s) of the site and some of the students entered into a dialogue with the context of the place and develop feelings about the place. This dialogue was intended to lead to the discovery of all the phenomena in the place, and each student derived his/ her own meanings from the context of the place. Especially the students with examples of combination and abstraction felt the spirit of the place in a profound way. Interestingly, none of the operations mentioned generated 
entirely new knowledge because the result was always dependent on or constructed with their existing knowledge.

Cognitive operations are used in design studios, but very rarely associated with traditional contexts. However, in architectural education, dealing with the tradition of local architecture might be a source of inspiration for the designs of students. As Özaslan (2011) claims, there should be new awareness in architectural education to reclaim a cultural approach, which would be a stimulating agent for the production of built environments where local conditions, characteristics and preferences determine the urban form and its architecture.

A final word should go to the benefits of study trips in creating consciousness about the architectural assets of the local culture. Creations in architectural education are based on the world of experiences, sensations and perceptions since the existing built environment already forms the cognitive repertoire of architecture students before they start a formal course. The benefits of perceiving the treasures of the place and local architectural values are believed to increase students' sense of responsibility and care for the place. As a total sensuous experience, this is believed to indicate the promising role of historical built environments in contemporary architectural education.

\section{ACKNOWLEDGMENTS}

The authors are indebted to Christopher Wilson (Architecture \& Design Historian) from the Ringling College of Art and Design who generously shared his time and intellectual capacities by reading final version of this work and making suggestions.

\section{BIBLIOGRAPHY}

AKÇA, B.Ö., ERDOĞAN, E., AKALIN, A. (2015) Mimarların Halkın Dilini Anlamasına Yönelik Bir Çalışma; Mimar ve Mimar Olmayan Benzerliği, METU Journal of the Faculty of Architecture 32(2) 171-89.

ANTONIADES, A. (1992) Poetics of Architecture: Theory of Design, Van Nostrand Reinhold, New York.

BROOK, I. (2001) Can 'Spirit of Place' Be a Guide to Ethical Building?, Ethics and the Built Environment, ed.F. Warwick, Routledge, New York and London;139-51.

CARMONA, M., HEATH, T., OC, T., TIESDELL, S. (2003) Public PlacesUrban Spaces: The Dimensions of Urban Design, Architectural Press, Oxford.

CASAKIN, H. (2004) Metaphors in the Design Studio: Implications for Education, Proceedings of EEPDE 2004, The 7th International Conference on Engineering and Product Design Education, ed. P.Lloyd, N. Roozenburg, C. McMahon, E. Brodhurst, Delft; 265-73.

CASAKIN, H. (2006) Assessing the Use of Metaphors in the Design Process, Environment and Planning B: Planning and Design 33(2) 253-68.

CASAKIN, H. (2007) Metaphors in Design Problem Solving: Implications for Creativity, The International Journal of Design 1(2) 21-32.

CASAKIN, H. (2012) An Empirical Assessment of Metaphor Use in the Design Studio: Analysis, Reflection and Restructuring of Architectural Design, International Journal of Technology and Design Education 22(3) 329-44. 
COYNE, R., SNODGRASS A., MARTIN, D. (1994) Metaphors in the Design Studio, Journal of Architectural Education 48(2) 113-25.

FEZ-BARRINGTEN, B. (2012) Architecture: The Making of Metaphors, ed. E. Hart, Cambridge Scholars Publishing, Newcastle upon Tyne;1-70.

GENTNER, D., BOWDLE, B., WOLFF, P., BORONAT, C. (2001) Metaphor is Like Analogy, The Analogical Mind: Perspectives from Cognitive Science, ed. D. Gentner, K. J. Holyoak, B. N. Kokinov, MIT Press;199-253.

HEIDEGGER, M. (1971) Poetry, Language, Thought, translated by Albert Hofstadter (2001) Harper \& Row Publishers, New York; 143-59.

INDURKHYA, B. (1992) Metaphor and Cognition: An Interactionist Approach, Kluwer Academic Publishers, Dordrecht.

KIM, M. (2013) A Theory of Urban Design, GSTF International Journal of Engineering Technology 2(1) 151-7.

KOCA, S.K., ULUENGİN, Ö. (2014) How does Concept Transform into Product? An Appraisal of Analogy-based Design Practices in Architecture Education, Procedia - Social and Behavioral Sciences (152) 25-30.

LAKOFF, G. (1993) The Contemporary Theory of Metaphor, Metaphor and Thought, ed. A. Ortony, Cambridge University Press, Cambridge; 202-51.

LASSIG, C. J. (2013) Approaches to Creativity: How Adolescents Engage in the Creative Process, Thinking Skills and Creativity (10) 3-12.

MARTINDALE, C. (1989) Personality, Situation, and Creativity, Handbook of Creativity: Perspectives on Individual Differences, ed. J. A. Glover, R. R. Ronning, C. R. Reynolds, Plenum Press, New York; 211-32.

MUMFORD, M. D., MOBLEY, M. I., REITER-PALMON, R., UHLMAN, C. E., DOARES, L. M. (1991) Process Analytic Models of Creative Capacities, Creativity Research Journal 4(2) 91-122.

NORBERG-SCHULZ, C. (1996) The Phenomenon of Place, Theorizing a New Agenda for Architecture: An Anthology of Architectural Theory 1965-1995, ed. K. Nesbitt, Princeton Architectural Press, New York; 414-28.

NORBERG-SCHULZ, C. (1980) Genius Loci: Towards a Phenomenology of Architecture, Rizzoli, New York.

ÖZASLAN, N. (2011) The Role of Architectural History in Building Modern Turkish Architecture, The Journal of International Soial Research 4(17) $339-47$.

ÖZER, E., KORKMAZ, H. (2014) Tarihsel Süreçte Aizanoi Kentindeki Dört Yapida Tahrip ve Koruma, Pamukkale Üniversitesi Sosyal Bilimler Enstitüsü Dergisi (18) 11-20.

PIAGET, J. (1968) Genetic Epistemology, Columbia University Press, New York.

RAPOPORT, A. (2006) Vernacular Design as a Model System, Vernacular Architecture in the 21st Century: Theory Education and Practice, ed. L. Asquith, M. Vellinga, Taylor and Francis, London;179-98.

RHEIDT, K. (1998) Aizanoi Çavdarhisar Rehberi. Ministry of Culture of Turkey, Ankara. 
ROOT-BERNSTEIN, R. S. (1991) Teaching Abstracting in an Integrated Art and Science Curriculum, Roeper Review 13(2) 85-90.

ROOT-BERNSTEIN, R. S., ROOT-BERNSTEIN, M. M. (1999) Sparks of Genius: The Thirteen Thinking Tools of the World's Most Creative People, Houghton, New York.

RUNCO, M. A. (2007) Creativity Theories and Themes: Research, Development and Practice, Elsevier Academic Press, Amsterdam.

SCHÖN, D. A. (1984) The Architectural Studio as an Exemplar of Education for Reflection-in- Action, Journal of Architectural Education 38(1) 2-9.

SIMONTON, D. K. (1999) Origins of Genius: Darwinian Perspectives on Creativity, Oxford University Press, USA.

STERNBERG, R. J. (1999) A Propulsion Model of Types of Creative Contributions, Review of General Psychology 3(2) 83-100.

UNESCO World Heritage Centre (1972) Tentative lists [http://whc.unesco. org/en/tentativelists/5724] Access Date (04.10.2017).

URAZ, T.U., BALAMIR, A. (2006) Themes of Place and Space in Design Teaching: A Joint Studio Experiment in Amasya, METU Journal of the Faculty of Architecture 23(1) 1-18.

van de KAMP, M.T., ADMIRAAL, W., RIJLAARSDAM, G. (2016) Becoming Original: Effects of Strategy Instruction, Instructional Science 44(6) $543-66$.

WARD, T. B., PATTERSON, M. J., SIFONIS, C. M. (2004) The Role of Specificity and Abstraction in Creative Idea Generation, Creativity Research Journal 16(1) 1-9.

WEISBERG, R. W. (1995) Case Studies of Creative Thinking: Reproduction Versus Restructuring in The Real World, The Creative Cognition Approach, ed. S.M. Smith, T. B. Ward, R. A. Finke, MIT Press, Cambridge; 53-72.

WELLING, H. (2007) Four Mental Operations in Creative Cognition: The Importance of Abstraction, Creativity Research Journal 19(2-3) 163-77.

Alındı: 10.09.2017; Son Metin: 01.02.2019

Anahtar Sözcükler: Yere ilișkin farkındalık tarihsel bağlam; Aizanoi; mimari tasarım eğitimi; bilişsel tutumlar.

\section{TARIHSEL BAĞLAMDA YER BİLINCINİN KAVRANMASI: MIMMARİ TASARIM EĞİTIMINDE METAFORLAR}

Makale, mimarlık eğitiminin temel bileşeni olan tasarım stüdyosundaki bilişsel tutumlar ve bu tutumların bir tasarım problemi üzerinden ele alınmasını içerir. Çalışmada, projenin konumlanacağı yerin karakteri ve bu karakterin mimari tasarım sürecini etkilediği kabulüyle, tarihsel bağlamda yer bilincinin irdelenmesine yönelik bir tartı̧̧ma geliştirilmektedir. Bu kapsamda, ikinci sınıf mimarlık öğrencilerinin mimari tasarım dersindeki süreçleri analiz edilerek, yerden elde ettikleri verilerin tasarımlarına olan katkıları irdelenmektedir.

Makalede konu edilen tasarım stüdyosunun öğretim yaklaşımı, tarihi çevrelerde tasarım problemleri üzerinde yoğunlaşarak yer bilincine vurgu yapmaktır. Tasarım sürecinde yer farkındalığını kazandırmak 
için, öğrencilerin yeri bizzat deneyimleyerek ve bedensel-duyusal ilişkiler geliştirerek okumaları önemsenmektedir. Bu okuma, yerin gizli ve keşfedilmeyi bekleyen ruhunu hissetmeyi ve tasarıma yönelik ipuçları yakalamayı hedefler. Analizi yapılan mimari tasarım örnekleri, 2016-2017 akademik yılı bahar döneminde, ikinci sınıf öğrencilerinin Anadolu'daki antik yerleşimlerden birisi olan Aizanoi (Çavdarhisar) için gerçekleştirdikleri çalışmaya ilişkindir. Ondört haftalık tasarım süreci sonunda, farklı öğrenci yaklaşımları ortaya çıkmıştır. Öğrencilerin bir bölümü, yerin ruhuna metaforik bir yaklaşımla vurgu yapmıştır. Bu projeler Welling'in (2007) tanımladığı bilişsel tutumlar uygulama, analoji, kombinasyon ve soyutlama kapsamında analiz edilmiştir. Uygulama olarak nitelendirilen, var olanın aynen kopyalanması yaklaşımı, tasarım stüdyosunun eğitim anlayışı çerçevesinde desteklenen bir yöntem değildir. Diğer üç kategoride yer alan projelerin analiz sonuçlarına göre yere ilişkin farkındalık, analojik yaklaşımlarda oldukça düşüktür, kombinasyon grubundaki çalışmalarda yer bilincinin önemli derecede arttı̆̆ ve "soyutlama" içeren projelerde ise en üst düzeyde olduğu görülmektedir. Metaforik bir tavır sergilemeyen projelerde ise, grafik mükemmeliyet ön planda tutularak yerleşim dokusunun ölçeği göz ardı edilmiştir. Mükemmel grafik kurgunun önceliği fonksiyonun gereklerini yerine getirmek ve erişilebilirlik probleminin çözümüdür. Özetle metaforik ve biçimsel tavırların her ikisi de öğrencilerin mevcut bilgileri ve yere ilişkin deneyimleri ile inşa edilerek geliştirilmiştir, ancak metaforik yaklaşımların daha derin bir yere ait olma kaygısı taşıdığı görülmektedir.

\section{THE COMPREHENSION OF PLACE AWARENESS IN A HISTORICAL CONTEXT: METAPHORS IN ARCHITECTURAL DESIGN EDUCATION}

This study examines cognitive operations in the design studio - the main component of architectural education - and reviews these operations with regard to a design problem. It also develops an argument for performing an analysis of place awareness in historic context while considering the characteristics of the place where the project will be located and accepting that these characteristics affect the architectural design process. Accordingly, the processes experienced by second-year architecture students on architectural design courses will be analyzed, and the contributions of the data collected from the place to their designs will be evaluated.

The educational concept of the design studio, which was also examined in this study, focuses on the design problems in historical environments and implies place awareness. Importance is attached to the idea that students experience and assess the place by developing body-sensory relationships in order to acquire place awareness during the design period. The process of assessing aims to grasp the secret and unexplored spirit of the place and obtain clues regarding the design. The analyzed architectural design cases are related to the study of Aizanoi - an ancient settlement in Anatolia (Çavdarhisar) - conducted by the second-year students in the spring term of the 2016-2017 academic year. Different student approaches emerged at the end of the design process, which lasted fourteen weeks. Some of the students emphasized the spirit of the place with a metaphorical reasoning. These projects were analyzed under the context of cognitive operations; application, analogy, combination and abstraction as defined by Welling (2007). The approach, imitating an already-existing object, which is also 
regarded as "application", is not a method that is supported in regard to the educational approach of the design studio. According to the results of the analysis of the projects in the other three categories, place awareness is low in the analogical approaches. In addition, evidence indicates that place awareness significantly increased in the studies in the "combination" group and reached the highest degree in those projects containing "abstraction". Regarding the projects that did not present a metaphorical reasoning, graphical perfection was prioritized but the scale of the urban texture was neglected. The priority for graphical perfection is to fulfill the functional requirements and solve the accessibility problems. To sum up, both metaphorical and structural attitudes were developed by the contributions from the students' current knowledge and experiences regarding the place, but evidence suggests that metaphorical approaches are concerned with belonging to the "place" in a deeper sense.

ESRA ÖZKAN YAZGAN; B.Arch, M.Sc., PhD.

Received her B.Arch from Uludağ University Faculty of Architecture in 2001. Earned her M.Arch and PhD. degree in architecture from Gazi University in 2005 and 2012 respectively. Major research interests include; adaptive reuse of architectural heritage, industrial heritage, urban conservation and architectural design in the historic environment. esraozkan@gazi.edu. tr.

AYSU AKALIN; B.Arch, M.Sc., PhD.

Received her B.Arch from Gazi University Faculty of Architecture in 1986, M.A. in restoration from Middle East Technical University in 1991. Earned her Ph.D. degree in architecture from the University of Manchester School of Architecture in 1996. Her research interests include environmental psychology, image sensation and perception, meaning of space, existential space, regionalism and place identity. aysuakalin@gazi.edu.tr. 
